\title{
The role of commercial lexeme in the development of the intellectual potential of modern students
}

\author{
Toshpulatov Dilshodjon Abdurafiqovich \\ Teaching Assistant of Tashkent University of Information Technologies of Samarkand branch \\ named after Muhammad al - Khwarizmi \\ E-mail: toshpulatov.dilshodjon2705@mail.ru \\ Phone: +998937266032
}

\begin{abstract}
ANONTATION
In this article, the role of commercial vocabulary is becoming very important for the development and formation of the intellectual potential of modern students. Monitoring technologies of teaching foreign (English) language are considered. In many developed countries, work is underway to develop telecommunications technology failures, special attention is paid to commercial language in the development of the intellectual potential of modern students. As stated in scientific books, the first priority for professional development and the personality of a person is the formation of the intellectual potential of a modern student. To achieve these goals, first we must know the features of professional development of the individual.
\end{abstract} Keywords: rate, credit, foreign exchange, exchange, auction, education, development, monitoring technologies, active account,

\section{INTRODUCTION}

Currently, in many developed countries, work is underway to develop telecommunications technology failures, special attention is paid to commercial language in the development of the intellectual potential of modern students. As stated in scientific books, the first priority for professional development and the personality of a person is the formation of the intellectual potential of a modern student. To achieve these goals, first we must know the features of professional development of the individual.

For this, we must know that such a methodology of teaching foreign languages. Teaching a foreign language as a means of communication can be successful only if it is also based on fundamental theoretical principles that illuminate and determine the essence of teaching a foreign language.

The transition to market relations, the adoption of various forms of ownership and methods of management cause increased interest in various words of the population in economic and commercial problems. The publication of scientific and popular literature on these problems is expanding in our republic, especially in Uzbek and English. Teaching of economic and commercial disciplines in universities and technical schools in Uzbek and English is becoming increasingly important. The consistent implementation of the law of the Republic of Uzbekistan on the state language and improving the role of teaching foreign languages significantly expands the training of specialists and, consequently, teaching in Uzbek and English. [1. 26-27 p].

The practice of teaching economic and commercial disciplines shows that the students' assimilation of educational and scientific material is seriously hampered by the lack of translation of the basic concepts and terms of these disciplines in Uzbek and English. The aim of this work is to provide material terminological assistance to university students, university students, technical schools, students, FPK, practical workers studying economic and commercial disciplines. As suggested by the dictionaries of economics, it contains the most common words and terms for the course "Analysis of Economic Activities", their translation from Russian into Uzbek and, if necessary, a brief explanation of the meaning of the terms. [5, 17p].

\begin{tabular}{|l|l|l|c|}
\hline № & Russian & Uzbek & English \\
\hline 1 & Абсолют & Мутлоқ & absolute \\
\hline 2 & Аванс & Бунак, аванс & аdvance \\
\hline 3 & Акция & Акция, қимматбахо қоғоз & Асtion \\
\hline & & & тахлил \\
\hline
\end{tabular}




\begin{tabular}{|c|c|c|c|}
\hline 5 & Активный счет & Фаол счет & $\begin{array}{l}\text { Active } \\
\text { account }\end{array}$ \\
\hline 6 & Ассортимент & Махсулот турлари & Range \\
\hline 7 & Аукцион & Кимошди савдо аукцион & Auction \\
\hline 8 & Базар & Бозор & Bazaar \\
\hline 9 & Базарные цены & Бозор нархлари & $\begin{array}{l}\text { The bazaar } \\
\text { prices }\end{array}$ \\
\hline 10 & $\begin{array}{l}\text { Банк } \\
\text { международных } \\
\text { расчетов }\end{array}$ & $\begin{array}{l}\text { Халқаро хисоб-китоблар } \\
\text { банки (жамғармаси) }\end{array}$ & $\begin{array}{l}\text { The bank } \\
\text { for } \\
\text { international } \\
\text { settlements }\end{array}$ \\
\hline 11 & $\begin{array}{l}\text { Баланс спроса и } \\
\text { предложений по } \\
\text { товарам }\end{array}$ & $\begin{array}{l}\text { Моллар сохасидаги талаб ва } \\
\text { таклиф мувозанати }\end{array}$ & $\begin{array}{l}\text { The balance } \\
\text { of demand } \\
\text { and supply } \\
\text { for goods }\end{array}$ \\
\hline 12 & Бартер & $\begin{array}{l}\text { Бартер, валютасиз бевосита } \\
\text { мол айри-бошлаш }\end{array}$ & Barter \\
\hline 13 & Банкрот & $\begin{array}{l}\text { Банрот инқрозга учраш } \\
\text { (синган савдогар, сингган } \\
\text { капиталист) }\end{array}$ & Bankrupt \\
\hline 14 & Бизнес & $\begin{array}{l}\text { Корчалонлик, } \\
\text { бизнес(даромадли иш, } \\
\text { тижорат иши) }\end{array}$ & Business \\
\hline 15 & Валютный кризис & Валюта тенглиги & $\begin{array}{l}\text { Currency } \\
\text { crisis }\end{array}$ \\
\hline 16 & Валютный курс & $\begin{array}{l}\text { Валюта курси (мамлакат пул } \\
\text { бирлигининг бошқа } \\
\text { мамлакатлар пул бирлигига } \\
\text { нисбатага ифодаланган } \\
\text { қиймат даражаси) }\end{array}$ & $\begin{array}{l}\text { Exchange } \\
\text { rate }\end{array}$ \\
\hline 17 & Ввозной товар & $\begin{array}{l}\text { Чет элдан келтириладиган } \\
\text { мол, четдан келтириладиган } \\
\text { мол }\end{array}$ & $\begin{array}{l}\text { Import } \\
\text { goods }\end{array}$ \\
\hline 18 & Внешний долг & Ташқи қарз & $\begin{array}{l}\text { External } \\
\text { debt }\end{array}$ \\
\hline 19 & Внешняя торговля & Ташқи савдо & $\begin{array}{l}\text { Foreign } \\
\text { trade }\end{array}$ \\
\hline 20 & $\begin{array}{l}\text { Внутренний } \\
\text { товарооборот }\end{array}$ & Ички мол обороти & $\begin{array}{l}\text { Internal } \\
\text { trade }\end{array}$ \\
\hline 21 & $\begin{array}{l}\text { Внутренняя } \\
\text { торговля }\end{array}$ & Ички савдо & $\begin{array}{l}\text { Domestic } \\
\text { trade }\end{array}$ \\
\hline 22 & $\begin{array}{l}\text { Государственный } \\
\text { доход }\end{array}$ & Давлат даромади & $\begin{array}{l}\text { State } \\
\text { income }\end{array}$ \\
\hline 23 & $\begin{array}{l}\text { Государственный } \\
\text { заказ }\end{array}$ & Давлат буюртмаси & State order \\
\hline 24 & Готовая продукция & Тайёр махсулот & $\begin{array}{l}\text { Finished } \\
\text { products }\end{array}$ \\
\hline 25 & Движение товаров & Мол харакати & $\begin{array}{l}\text { The } \\
\text { movement } \\
\text { of goods }\end{array}$ \\
\hline 26 & Дебет & $\begin{array}{l}\text { Дебет, кирим, тушум(криш- } \\
\text { чиқиш дафтарининг хамма } \\
\text { киримлари ва ундуриладиган } \\
\text { қарзлар ёзадиган томон) }\end{array}$ & Debit \\
\hline 27 & $\begin{array}{l}\text { Договор купли - } \\
\text { продаж }\end{array}$ & Олди-сотди шартномаси & $\begin{array}{l}\text { The contract } \\
\text { of sale }\end{array}$ \\
\hline 28 & Цена товара & Мол бахоси, нархи & $\begin{array}{l}\text { The price of } \\
\text { the goods }\end{array}$ \\
\hline 29 & Цена продавца & Сотувчи нархи & $\begin{array}{l}\text { The price of } \\
\text { the seller }\end{array}$ \\
\hline
\end{tabular}

This is now the only manual for studying this discipline and the need arises for a more accurate understanding of the terms used. The dictionary translates terms from Russian into Uzbek. But we will have to use other languages (for example, English and Tajik), although it is very difficult to create new dictionaries 
of Russian-Uzbek-English commercial terms of trade that helps to understand commercial vocabulary in the development of the intellectual potential of modern students, we will look at, compare typology from a point of view. For this table are shown as an example of not splintering words.

The art and skill of the teacher lies precisely in the ability to combine cordiality with wisdom (V. Sukhomilinsky). Among them there are students who have abilities, giftedness and inclinations. For the development of the intellectual potential of modern students, it is necessary to know and develop their abilities.

Abilities are individual psychological characteristics that distinguish one person from another and are related to the successful implementation of an activity. Speaking of abilities, it is necessary to keep in mind the following: [3, 45p ].

* These are the features that distinguish one person from another. B.M.Teplov considers the most important features of abilities to be the individual originality of productive activity, the originality and originality of the techniques used in activity.

* Abilities serve the successful completion of an activity. Some researchers, for example N.A. Menchinskaya, believe that in this case it is more logical to talk about learning as success in acquiring skills, knowledge, and skills.

* Abilities are characterized by the possibility of transferring the developed skills to a new situation. Moreover, the new task should be similar to the tasks that were solved earlier, not by a sequence of methods of action, but by requirements for the same mental properties of a person. The basis of abilities is makings. [4, 2-9p].

Inclinations are natural prerequisites that are a condition for the development of abilities, not only in the sense that they give a peculiarity to the process of their development, but also in the sense that, in certain redistributions, they can determine the content side and affect the level of achievement. The makings include not only the anatomical and morphological and physiological properties of the brain, but also mental properties to the extent that they are directly and directly caused by heredity. Abilities - a dynamic concept. They are formed, developed and manifest in activity.

General and special abilities. Special abilities are abilities for certain types of activities (mathematical abilities, musical abilities, pedagogical, etc.). General abilities are the ability to develop special abilities.

Endowment is a qualitatively peculiar combination of abilities, on which the possibility of achieving greater or lesser success in the performance of one or another activity depends. The concept of abilities is usually associated with mental activity. Activity is a way of a person's relationship to the outside world, consisting in the transformation and submission to his goals of man. [4, 2-9p].

Human activity has a certain similarity with the activity of the animal, but differs in creativetransforming in relation to the surrounding world. For its development in methodological work, it is necessary to use innovative forms that provide emancipation, professional self-affirmation and self-expression of the teacher.

Innovative approaches to teaching English are associated primarily with the changing role of the teacher. In modern conditions, it is very important that the teacher does not give students ready knowledge, but indicates the path to acquiring knowledge, and teaches to acquire knowledge. This is especially important when the teacher teaches English as a second language.

The methodology is a generalized model for the implementation of the main components of the educational process in a foreign language, based on the dominant idea of solving the main methodological problem. In this regard, in the process of teaching a foreign language the following are practiced: demonstration, explanation and exercise; each of the components can be represented by a number of options. The demonstration most often finds its expression in that methodological speech as communicative units equally in the teaching of oral speech and reading; the explanation is carried out in cases where students need to gain some knowledge on various aspects of the language system, on understanding the essence of speech patterns of different types. Moreover, such work can be carried out at different stages of work, at the stage of consolidation of the studied material, with the systematization and repetition of the thematically combined terminological or grammatical material during the lecture presentation.

\section{CONCLUSION}

Finally, the exercise as the main and main way of working in practical classes has an extremely wide range of applications, which is implemented at all stages of the formation of skills, at all stages of mastering one or another language material or different types of speech activity.

Teaching English in modern conditions requires a completely new, innovative approach from a vocabulary teacher, both to the content of the lesson and to the choice of educational technologies, effective 
teaching methods, and the diagnosis of the level of English proficiency as non-native.

Innovative approaches to teaching English in a political environment are based, first of all, not only on the awareness of the importance of the problem of the low level of preparation of students in the English language, understanding that the reason for poor knowledge of the English language is primarily associated with the problem of the social and psychological adaptation of the student to a new culture, to new traditions, values, guidelines, but also on mastering the principles of an active approach to teaching English as a second language. [2, 428p.].

An innovative approach to teaching English as non-native is relevant in connection with the introduction of new forms. This requires the vocabulary to choose effective forms of working with texts of different types and styles of speech, listening, speaking. In this regard, special attention is required to the lessons of speech development, the lessons of a comprehensive analysis of the text.

To create your own text, to interpret the text proposed for analysis, by students. To express their thoughts in a foreign language, it is not enough to know the rules. To do this, you must first expand the active dictionary. How to do this in English lessons? The system of pre text exercises, which is typical for the methodology of teaching a foreign language, helps. This system consists in the following: drawing up an idea of the content of the text as a whole, a language conjecture at the level of situational models; determining the meaning of unfamiliar words in the context of word-formation analysis of syntactic structures. recognition of international vocabulary; compilation of a text by analogy; inclusion of keywords in the text, etc [5,17p].

An innovative approach requires every vocabulary to master the teaching of English as a foreign language, understanding that students perceive the laws of the English language through the prism of the laws of their native language, and this is the cause of many spelling and even punctuation errors. Such errors are classified as interference.

\section{REFRENCES}

[1] Abdullaev Yu.N. Bushuy A.M. "Communicative Methods of Teaching Foreign Languages and Foreign Pedagogical Experience” - Samarkand 2001, 26-27 p.

[2] Sherba L.V. The language system and speech activity - L .: Science. LO, 1974 -428p.

[3] Musinov. S, Murtazaeva U, Bakhromova A. Professional Psychology - Samarkand 2018 -45p.

[4] Abdukarimov I.T., Pardaev M.K. "Russian - Uzbek Dictionary of Economic Trade Terms". Tashkent1992 2-9p.

[5] Lukhovitsky M.V. Methods of teaching foreign languages. Moscow Higher School 1981, 17 p. 